\title{
Assessing the Quality of Hospitality Services IN ECO-LODGES
}

\author{
By \\ Ahmed Saleh Saleh \\ Faculty of Tourism and Hotels \\ Mansoura University \\ Mohamed Abd El Fattah Zohry \\ Ahmed Hassan Metwaly \\ Lecturer of Hotel management- \\ Assoc. Prof of Hotel management- \\ Faculty of Tourism and Hotels - \\ Mansoura University \\ Faculty of Tourism and Hotels - \\ Mansoura University

\section{Research Journal of the Faculty of Tourism and Hotels Mansoura University}

ISSUE NO. 2, DECEMBER. 2017

مجلة كلية السياحة والفنادق - جامعة المنصورة

علد (r) - ديسمبر rاهن 


\title{
ASSESSING THE QUALITY OF HOSPITALITY SERVICES IN ECO-LOdGES
}

\author{
Ahmed Saleh Saleh Mohamed Abd El Fattah Zohry Ahmed Hassan Metwaly
}

\begin{abstract}
In order to understand customers' perceptions about the quality of hospitality services provided in eco-lodges or any type of hotels, the current level of quality should be assessed from the customers' point of view.

The current study aims to assess the level of quality of hospitality services provided in eco-lodges. To achieve this objective, a selfadministrated questionnaire was developed and distributed on a random sample of customers stayed in the investigated eco-lodges which were ten eco-lodges (according to the Egyptian Hotel Guide,2013) in Siwa and Nuibaa during the period from December 2016 to June 2017, to investigate their perceptions towards quality of hospitality services provided. The questionnaire consisted of six sections that covered (customers' demographic data, popularity of eco-lodges, source of information, reasons of staying in an eco-lodge, list of ten dimensions which evaluates the level of quality according to the Lodging Quality Index (LQI) and Overall satisfaction). A sum of 400 forms was distributed among them. The number of the returned questionnaires was 372 forms (93\%); only 355 forms $(95.43 \%)$ of the returned forms were valid. The findings of the study indicated that there were positive perceptions and general satisfaction towards the quality of the hospitality services provided in the investigated eco-lodges. Based on the study findings, the main recommendations were: Offering a variety in menu items and applying standard recipes of menus' items, increasing the number of eco-lodges' rooms and guest supplies, adding more recreational facilities.
\end{abstract}

Keywords: Service Quality, Eco-lodges and Lodging Quality Index. 


\section{تقييم جودة خدهات الضيافة فى الفنادق البيئية}

تهدف هذه الدراسة إلى تقييم جودة خدمات الضيافة فى الفنادق البيئية . ولتحقيق هذه الهدف قام الباحثون بتصميهم استمارة إستقصاء آراء العملاء تم تطبيقها على عينة عشوائية من الفنادق البيئية والتى بلغ عددها عشرة) طبقا لدليل الفنادق المصريـة (2013,فى كل من مدينة سيوة ومدينة نويبع خلال الفترة من ديسمبر 2016 إلى يونيه 2017 وقد تضمنت الإستهارة ستة أجزاء; الجزء الأول لتوضيح البيانات الديموجرافية للعمالاء ,والجزء الثانى لكثف شعبية الفنادق البيئية .أما الجزء الثالث فقد كان عن مصادر الحصول على المعلومات عن الفندق البيئى ,واختص الجزء الرابع بأسباب الإقامه بفندق بيئى ,اشتهل الجزء الخامس على عشرة أبعاد تضهنت أربعة وخمسون متغيرا طبقا لنهوذج) مؤشر جودة الإقامة (وتم استخدام مقياس ليكرت الخهاسى ) موافق بشده-موافق-محايد-غيرموافق-غير موافق بشدة .(وقد تناول الجزء موده السـادس والأخير تحديد مستوى القبول والرضا العام للعملاء .وقد توصلت الدراسـة إلى وجود مستوى تصور إيجابى جيد لدى العملاء تجاه خدمات الضيافة فى الفنادق البيئية محل الدراسـة .وبناءا على نتائج هذه الدراسة تم إستخلاص مجموعة مـن التوصيات للتحسين المستهمر لجودة خدمات الضيافة فى الفنادق البيئية لكى تتوافق مـع توجهات وتوقعات العملاء وتحقق مزيداً من الرضا.وكانت بعض هذه التوصيات كا يلى : إضافة أصناف متنوعة لقوائم الطعام وتطبيق الوصفات القياسية, وضع الفئات الخاصة والمجموعات فى الإعتبار رزيادة عدد الغرف لكى يتلاءم مـ الزيادة فى نسب الإشغال, زيادة إمـادات العملاء داخل الغرف, رفع مستوى خلدمـة الإثـراف الداخلى, إنشاء بازار لبيع المشغولات اليدوية والمحلية الصنح, إضافة بعض التسهيلات الترفيهية ) مكتبة رمراقبة النجوم رركوب الخيل..الخ (وإستغلال العيون الكبريتية والطبيعية فى الإستشفاء والترفيه للعملاء. الكامثات الداله :جودة الخدمـة -الفنادق البيئية-مؤشر جودة الإقامـة. 


\section{Introduction}

A rapidly changing business environment, changing customer demands, and increasing competition has been a challenge for many of today's hospitality companies (Cho et al., 2006). The gradual rising in the importance of hospitality for countries' economies have led to an increase in the number of hospitality establishment nowadays, and strengthened the competition environment. As for all the establishments, one of the main reasons for the hotels is obviously to stay competitive as well. The way for that is to make the hotel more attractive than the competitors (Didin and Köroğlu, 2008). Eco-lodges are accepted as one of the new trends in the hotel industry in recent years. An important part is that the travelers usually live in the industrialized metropolitan areas, Problems in big cities such as noise, environmental pollution; traffic and overpopulation are increasing the people's longing for the nature (Holjevac, 2003). Eco-lodges offer their environmentally aware customers a holiday alone with nature, and thus gain an important competitive advantage from providing hospitality services like accommodation services, food and beverage services and recreational facilities). (Bohdanowicz, 2005)

Service quality plays a vital role in the success of any hospitality services establishment. Customers' interaction level with various aspects of the establishment in the delivery and consumption of hospitality services is high. Customers always evaluate the level of hospitality services' quality by making a comparison between their perceptions of services delivery and services they actually received. Moreover, the quality of hospitality services also affect on the retention of the customers (Sandoff, 2005), and many organizations used it as a competitive advantage in their strategies between their competitors (Nadiri and Hussain, 2005).

\section{Problem of the Study}

The problem of this study lies on answering the following questions:

hat are the perceptions of the investigated customers towards quality of hospitality services provided in eco-lodges?

hat are the strength and weakness points which are mentioned by the investigated customers towards quality of hospitality services provided? 


\section{Aim and Objectives of the Study}

This research aims to assess the level of quality of hospitality services provided in a sample of eco-lodges in Egypt. To achieve this aim, we used the following steps:

- Review the previous studies related to the research subject.

- Identify the perceptions of the investigated customers towards the quality of hospitality services (Accommodation services, Food and beverage services, Environmental and recreational facilities) provided in the investigated ecolodges.

- Develop a set of recommendations based on the results of the field study aims to enhance the quality of hospitality services provided.

\section{Literature of Review}

\section{Eco-lodge as a Type of Hospitality Establishment}

The term "eco-lodge" was formally launched on the market at the First International Eco-lodge Forum and Field Seminar held in 1994 at Maho Bay Camps in the U.S. Virgin Islands and Maho Bay Camps was determined as the first eco-lodge (Mehta, 2007 and Dizdareviç, 2010). Later, "The First International Eco-lodge Guidelines" was published in 2002 after the Second International Conference held in 1995 in Costa Rica, which defined the eco-lodge as "an industry label used to identify a naturedependent tourist lodge that meets the philosophy and principles of ecotourism" (Ceballos-Lascurain, 2008).

Wood (2002) stated that, "An eco-lodge is a five- to 75- room, lowimpact, nature-based, financially sustainable accommodation facility that helps protect sensitive neighboring areas; involves and benefits local communities; offers tourists an interpretive and interactive participatory experience, constructed and operated in an environmentally and socially sensitive manner.

According to The International Eco-lodge Guidelines, an eco-lodge should meet the following criteria, which are the key principles of ecolodges (Wood, 2002; International Finance Corporation, 2004; Mehta, 2007; Dizdareviç, 2010):

- Conserve the surrounding environment, both natural and cultural.

- Fit into its specific physical and cultural contexts through careful attention to form, landscaping and color, as well as the use of localized architecture.

- Use alternative, sustainable means of water acquisition and reduces water consumption. 
Meet its energy needs through passive design and combines these with their modern counterparts for greater sustainability.

- Endeavor to work together with the local community.

- Offer interpretative programs to educate both its employees and tourists about the surroundings natural and cultural environments.

Contribute to sustainable local development through research programs. Ecotourism is nature based tourism that includes education and interpretation of the natural environment and is managed in order to be ecologically sustainable. This definition illustrates that natural environment also included cultural aspects and that ecologically sustainable involves a suitable benefit to the local people and long term protection of the natural resources (Joshi, 2011).

\section{Service Quality Concept}

Regarding with the increased competition between establishments, The quality of services provided has become a popular area of academic research and has been considered as a competitive advantage and enhancing satisfying relationships with customers (Zeithaml, 2000).

Chiou and Shen (2006) defined the service quality as meeting or exceeding customer needs and expectations, and consequently to some extent it is the customers who eventually assess the quality of a product.

Eshghi (2008) agreed with Kosar and Rašeta (2005) that "The products' quality is the assessment of its usefulness, i.e. appropriateness to satisfy the customers' desires".

\section{Importance of Service Quality in Hospitality Industry}

Lovelocke (2001) mentioned that the perceptions and expectations of customers towards service are essentially to their satisfaction and loyalty. The perceptions of customers towards the service are what matters most as they form their first impression about the establishments' standards. So, hospitality managers should determine what customer satisfaction actually means to their customers (Gianesi and Correa 2004).

Jones et. al. (2002) agreed with Bowen and Chen (2001) that, Customer retention goes beyond satisfying the present expectations of the customers; instead it is helpful in anticipating their expectations so that they become loyal supporters and promoters for the company brand.

Relationship between Service Quality and Customer Satisfaction in Hospitality Industry

Service quality is an important factor of customer satisfaction. However, in hospitality industry assessing of the quality of services is a 
complicated issue, because of the intangibility nature of service itself which can be evaluated differently by each customer (Vanacore and Erto, 2002).

Minazzi (2008) agreed with Hoffman and Bateson (2001) that customer satisfaction is considered as a result of comparison between expectations and perceptions of customers. It depends on such dimensions as tangibility, reliability, empathy, assurance responsiveness and on additional aspects like price and personal situations that may occur during the service process.

\section{Research Methodology}

As mentioned previously, this study originated from a need to assess the quality of hospitality services provided in eco-lodges. To achieve this objective, a self-administrated questionnaire was developed and distributed on a random sample of customers stayed in the investigated eco-lodges during the period from December 2016 to June 2017 to investigate their perceptions towards quality of hospitality services provided. The features of investigated eco-lodges are represented in Table 1.

\section{Table 1: The Investigated Sample of Eco-lodges' Data}

\begin{tabular}{|c|c|c|c|c|c|}
\hline $\begin{array}{l}\text { Eco-lodge } \\
\text { Name }\end{array}$ & stars & Address & $\begin{array}{l}\text { Owner } \\
\text { Name }\end{array}$ & $\begin{array}{l}\text { Operator } \\
\text { Name }\end{array}$ & $\begin{array}{l}\text { Rms } \\
\text { No. }\end{array}$ \\
\hline $\begin{array}{l}\text { Adrere } \\
\text { Amellal }\end{array}$ & 3 & $\begin{array}{c}\text { Maraki } \\
\text { Village,Siwa } \\
\text {,Egypt }\end{array}$ & \multicolumn{2}{|c|}{$\begin{array}{l}\text { Environment } \\
\text { Quality for Tourism }\end{array}$} & 35 \\
\hline Taziry & 3 & $\begin{array}{c}\text { Inside El } \\
\text { Maraki } \\
\text { Village,Siwa, } \\
\text { Egypt }\end{array}$ & $\begin{array}{l}\text { Faysal } \\
\text { El } \\
\text { Shoaby }\end{array}$ & $\begin{array}{l}\text { Mohamed } \\
\text { El Sahrawy }\end{array}$ & 29 \\
\hline Basata & 2 & $\begin{array}{c}23 \text { Nuweiba- } \\
\text { Taba-Road } \\
\text { Nuweibá, } \\
\text { Janub Sina', } \\
\text { Egypt }\end{array}$ & \multicolumn{2}{|c|}{ Sherif El Ghamrawy } & $\begin{array}{c}21 \\
\text { Tent } \\
12 \\
\text { Huts }\end{array}$ \\
\hline Albabenshal & 3 & $\begin{array}{c}\text { Market } \\
\text { square main } \\
\text { gate fortress } \\
\text { of shali , } \\
\text { siwa, Egypt }\end{array}$ & \multicolumn{2}{|c|}{$\begin{array}{l}\text { Mounir Soliman } \\
\text { Nematallah }\end{array}$} & 14 \\
\hline $\begin{array}{l}\text { Shali } \\
\text { Lodge }\end{array}$ & 3 & $\begin{array}{l}\text { El Seboukha } \\
\text { St, Siwa, } \\
\text { Egypt }\end{array}$ & \multicolumn{2}{|c|}{$\begin{array}{l}\text { Siwa for Tourism } \\
\text { Development }\end{array}$} & 99 \\
\hline Talist & 3 & $\begin{array}{l}\text { Al Maraki } \\
\text { Road,Siwa } \\
\text { Oasis,Egypt }\end{array}$ & $\begin{array}{l}\text { El sayed } \\
\text { El } \\
\text { Domiaty }\end{array}$ & $\begin{array}{c}\text { Nabila } \\
\text { Aziz }\end{array}$ & 32 \\
\hline
\end{tabular}




\begin{tabular}{|c|c|c|c|c|c|}
\hline $\begin{array}{c}\text { Eco-lodge } \\
\text { Name }\end{array}$ & stars & Address & $\begin{array}{l}\text { Owner } \\
\text { Name }\end{array}$ & $\begin{array}{c}\text { Operator } \\
\text { Name }\end{array}$ & $\begin{array}{c}\text { Rms } \\
\text { No. }\end{array}$ \\
\hline Ghaliet & 3 & $\begin{array}{c}\text { Siwa Farms } \\
\text { Area ,Siwa } \\
\text { Oasis, Egypt }\end{array}$ & $\begin{array}{l}\text { Magdy } \\
\text { Ryad }\end{array}$ & $\begin{array}{c}\text { Bakrin } \\
\text { Mohamed }\end{array}$ & 14 \\
\hline $\begin{array}{l}\text { Taghaghien } \\
\text { Island }\end{array}$ & 2 & $\begin{array}{c}\text { Taghaghien } \\
\text { Island,Siwa, } \\
\text { Egypt }\end{array}$ & \multicolumn{2}{|c|}{ Boshra El-Gergawy } & 30 \\
\hline Dehiba & 2 & $\begin{array}{c}\text { Al maraki } \\
\text { Road,Siwa, } \\
\text { Egypt }\end{array}$ & \multicolumn{2}{|c|}{$\begin{array}{c}\text { Nature for Managing } \\
\text {,Owing Hotel and } \\
\text { Touristic Service } \\
\text { LTD }\end{array}$} & 50 \\
\hline Dream Oasis & 2 & $\begin{array}{l}\text { Qesm } \\
\text { Siwa,Siwa, } \\
\text { Egypt }\end{array}$ & \multicolumn{2}{|c|}{ Mohammed Adel } & 37 \\
\hline
\end{tabular}

Source: Egyptian Hotel Guide (2012/2013) and (Malem, 2015)*. *In Arabic

The questionnaire form consisted of six sections that covered (customers' demographic data, popularity of eco-lodges, source of information, reasons of staying in an eco-lodge, fifty-four attributes covering ten dimensions (Tangibility, Reliability, Credibility, Responsiveness, Competence, Courtesy, Security, Access, Communication and Understanding) according to the Lodging Quality Index (LQI) Each attribute was investigated by using a five Likert type scale (strongly agree agree - neutral - disagree - strongly disagree) and Overall satisfaction).

A sum of 400 forms was distributed among them. The number of the returned questionnaires was 372 forms (93\%); only 355 forms $(95.43 \%)$ of the returned forms were valid.

\section{Results and Discussions}

\section{Q 1: Respondents' Demographic Data}

This question aims to illustrate the respondents' demographic data with regard to (Gender, Age, Nationality and Education).

Table 2: The Respondents' Demographic Data

\begin{tabular}{|c|c|c|c|}
\hline \multicolumn{2}{|c|}{ Attributes } & Freq. & Perc. \% \\
\hline \multirow{3}{*}{ Gender } & Male & 198 & 55.5 \\
\cline { 2 - 4 } & Female & 157 & 44.5 \\
\hline \multirow{3}{*}{ Age } & Total & $\mathbf{3 5 5}$ & $\mathbf{1 0 0 \%}$ \\
\hline & Less than 30 years & 139 & 39.2 \\
\cline { 2 - 4 } & From 30 to less than 40 years & 87 & 24.5 \\
\cline { 2 - 4 } & From 40 to less than 50 years & 56 & 15.8 \\
\cline { 2 - 4 } & More than 50 years & 73 & 20.5 \\
\hline
\end{tabular}




\begin{tabular}{|c|c|c|c|}
\hline \multicolumn{2}{|r|}{ Total } & 355 & $100 \%$ \\
\hline \multirow{22}{*}{ Nationality } & Egyptian & 122 & 34.4 \\
\hline & Italian & 34 & 9.5 \\
\hline & Malaysian & 33 & 9.3 \\
\hline & Germany & 26 & 7.3 \\
\hline & Polish & 22 & 6.2 \\
\hline & American & 19 & 5.3 \\
\hline & French & 12 & 3.4 \\
\hline & Korean & 11 & 3.1 \\
\hline & Moroccan & 9 & 2.5 \\
\hline & Libyan & 9 & 2.5 \\
\hline & British & 8 & 2.3 \\
\hline & Canadian & 8 & 2.3 \\
\hline & \multicolumn{3}{|c|}{ Table 2Continued } \\
\hline & Attributes & Freq. & Perc. \% \\
\hline & Japanese & 8 & 2.3 \\
\hline & Emirati & 8 & 2.3 \\
\hline & Australian & 7 & 2.0 \\
\hline & Spanish & 5 & 1.4 \\
\hline & Finnish & 5 & 1.4 \\
\hline & Lebanese & 4 & 1.1 \\
\hline & Mexican & 3 & 0.8 \\
\hline & Russian & 2 & 0.6 \\
\hline \multicolumn{2}{|r|}{ Total } & 355 & $100 \%$ \\
\hline \multirow{4}{*}{ Education } & High school or equal & 13 & 3.7 \\
\hline & University degree & 258 & 72.6 \\
\hline & Post graduate & 84 & 23.7 \\
\hline & Other & 0 & 0 \\
\hline \multicolumn{2}{|r|}{ Total } & 355 & $100 \%$ \\
\hline
\end{tabular}

The findings of the customers' questionnaire form are illustrated in the following tabulated data. As seen in table (2) that represents the respondents' demographic data. It could be noticed that, $(55.5 \%)$ of the investigated respondents were males while $(44.5 \%)$ were females.

Concerning age, the age category less than 30 years represented (39.2\%). While (24.5\%) of the investigated respondents were of age category between 30 years to less than 40 years, however, number of respondents who were of age category from 40 years to less than 50 years represent 
(15.8 \%) Meanwhile, (20.5\%) of customers were of the age category more than 40 years.

By focusing on the nationalities of the respondents, it can be concluded that Egyptian nationality was the largest (34.3\%),

On the other hand, Russian, Mexican, Lebanese, Finnish and Spanish were the lowest category with percentages ranging from $0.6 \%$ to $1.49 \%$

At the same time, other nationalities ranged from $2 \%$ to $9.5 \%$.

This result means that the Tourism Development Authority should increase marketing activities in these low-level markets and expand into new markets to spread this type of hotel and encourage the domestic tourism in Egypt.

Also, it could be noticed that, the majority of the investigated respondents $(72.6 \%)$ are of the level of university degree. The respondents who were of the post graduate level represent $(23.7 \%)$. Meanwhile, (3.7 \%) of the investigated respondents were of the level of high school or equal.

\section{Q 2: Popularity of eco-lodge as a type of accommodation}

This question aims to identify to what extent the investigated respondents were aware about eco-lodge as a type of accommodation.

Table3: Popularity of eco-lodge as a type of accommodation

\begin{tabular}{|c|c|c|}
\hline Attribute & Frequency & Percentage \% \\
\hline Yes & 272 & 76.6 \\
\hline No & 83 & 23.4 \\
\hline Total & $\mathbf{3 5 5}$ & $\mathbf{1 0 0}$ \\
\hline
\end{tabular}

From the tabulated data, it could be concluded that more than three quarters of the investigated respondents $(76.6 \%)$ considered eco-lodges is a popular type of accommodation. Meanwhile, (23.4\%) stated that eco-lodge is unpopular for them.

The popularity of eco-lodge as a type of accommodation to the investigated respondents were mentioned the reasons to be unpopular. Their reasons listed as follows:

- Shortages in marketing for eco-lodge.

- Some eco-lodges offer their services at some high prices .

- The nature of eco-lodges, especially as they move away from modern technology and traditional means of entertainment.

\section{Q 3: Source of Information about this Eco-lodge}

he purpose of this question is to reveal the source of information that the investigated respondents knew the eco-lodge 
- Assessing the Quality of Hospitality Services in Eco-lodges

Table 4: Source of Information about Eco-lodge

\begin{tabular}{|r|c|c|}
\hline Attribute & Frequency & Percentage\% \\
\hline Previous experience & 55 & 15.5 \\
\hline Internet & 153 & 43 \\
\hline Friends and alternatives & 56 & 15.8 \\
\hline Travel agency & 87 & 24.6 \\
\hline Other & 4 & 1.1 \\
\hline Total & $\mathbf{3 5 5}$ & $\mathbf{1 0 0}$ \\
\hline
\end{tabular}

Data in table (4) showed that, the majority of respondents (43\%) got their information about eco-lodge from internet advertising. Meanwhile, (24.6\%) know about them from travel agencies, respondents who had previous experience and know them from their friends and relative represents (15.5\% and $15.8 \%)$ respectively.

Q4: Reasons of Staying in an Eco-lodge.

This question figures out the reason that make the investigated respondents stayed in an eco-lodge

Table 5: Reasons of Staying in an Eco-lodge

\begin{tabular}{|r|c|c|}
\hline \multicolumn{1}{|c|}{ Attribute } & Frequency & Percentage \\
\hline Relaxation & 103 & 29 \\
\hline To have a new experience & 131 & 37 \\
\hline Recreation & 48 & 13.5 \\
\hline Enjoying the nature & 62 & 17.4 \\
\hline Other & 11 & 3.1 \\
\hline Total & $\mathbf{3 5 5}$ & $\mathbf{1 0 0}$ \\
\hline
\end{tabular}

Data presented in table (5) revealed that more than one third (37\%) of the investigated respondents prefer to stay in eco-lodge to have a new experience. Meanwhile, (29\%) of them prefer to stay for relaxation. The respondents who stay for enjoying the nature and practice recreational activities represent $(17.4 \%$ and $13.5 \%)$ respectively.

Q5: Perceptions of the investigated respondents towards dimensions of hospitality service quality

This question aims to identify perceptions of the investigated respondents towards the quality of the hospitality services provided in the investigated eco-lodges. Data collected was presented in the following table: Table 6: Perceptions of the investigated respondents towards dimensions of hospitality service quality 


\begin{tabular}{|c|c|c|}
\hline Variables & \multirow{2}{*}{ Mean } & \multirow{2}{*}{ St.D } \\
\hline (1)Tangibility Dimension & & \\
\hline $\begin{array}{c}\text { - Check-in and check-out procedures were easy to } \\
\text { understand. }\end{array}$ & 3.75 & 0.72 \\
\hline - The guestroom is quiet. & 3.95 & 0.70 \\
\hline The front desk is visually appealing. & 4.06 & 0.68 \\
\hline $\begin{array}{l}\text { - The employees had a good appearance (clean, neat } \\
\text { uniforms). }\end{array}$ & 3.65 & 0.87 \\
\hline - The guestrooms are comfortable and clean. & 4.11 & 0.71 \\
\hline - Room service offered a good variety of menu items. & 2.41 & 1.29 \\
\hline $\begin{array}{c}\text { - Room service served food at a satisfactory } \\
\text { temperature. }\end{array}$ & 2.45 & 1.31 \\
\hline - The restaurant's atmosphere is suitable for you. & 4.20 & 0.76 \\
\hline - The food is good. & 4.12 & 0.73 \\
\hline $\begin{array}{l}\text { Environmental entertainment facilities and } \\
\text { services are available in this eco-lodge (i.e. } \\
\text { mountain climbing, safari, diving, bird watching, } \\
\text { etc.). }\end{array}$ & 3.31 & 0.73 \\
\hline $\begin{array}{c}\text { - The outdoor surroundings were visually attractive } \\
\text { and had an eco-design. }\end{array}$ & 3.90 & 0.76 \\
\hline - The eco-lodge was eco-friendly lighted. & 4.10 & 0.63 \\
\hline - $\quad$ Furnishings of the eco-lodge were appealing. & 4.21 & 0.73 \\
\hline $\begin{array}{l}\text { - The eco-lodge's interior and exterior were well } \\
\text { maintained. }\end{array}$ & 4.22 & 0.69 \\
\hline$\bullet \quad$ The eco-lodge was clean. & 4.20 & 0.79 \\
\hline Table 6 Continued & & \\
\hline Variables & Mean & St.D \\
\hline (2)Reliability Dimension & & \\
\hline Room service was consistent. & 2.54 & 1.36 \\
\hline $\begin{array}{l}\text { - Employees were able to accurately answer your } \\
\text { questions. }\end{array}$ & 4.36 & 0.76 \\
\hline - Your reservation was handled efficiently. & 4.23 & 0.66 \\
\hline Your guestroom was ready as promised. & 4.22 & 0.71 \\
\hline - You received the type of room requested. & 4.18 & 0.78 \\
\hline $\begin{array}{l}\text { - Enough towels, soap, etc., were found in your } \\
\text { room. }\end{array}$ & 3.75 & 1.26 \\
\hline - Charges at check out were accurate & 4.28 & 0.70 \\
\hline - $\quad$ Restaurant orders were filled correctly. & 4.09 & 0.84 \\
\hline The employees did what they said they would do. & 4.24 & 0.70 \\
\hline (3)Credibility Dimension & & \\
\hline You got what you paid for. & 4.23 & 0.71 \\
\hline $\begin{array}{l}\text { - Managers were frequently seen throughout the eco- } \\
\text { lodge. }\end{array}$ & 4.17 & 0.75 \\
\hline • The eco-lodge had a good reputation. & 4.24 & 0.76 \\
\hline (4)Responsiveness Dimension & & \\
\hline - Restaurant service was prompt. & 4.12 & 0.86 \\
\hline $\begin{array}{l}\text { - Informative literature about the eco-lodge was } \\
\text { provided. }\end{array}$ & 4.21 & 0.69 \\
\hline - Employees were willing to answer your questions. & 4.20 & 0.74 \\
\hline $\begin{array}{l}\text { Employees responded quickly to handle your } \\
\text { problems. }\end{array}$ & 4.08 & 0.90 \\
\hline
\end{tabular}




\begin{tabular}{|c|c|c|}
\hline \multicolumn{3}{|l|}{ Assessing the Quality of Hospitality Services in Eco-lo } \\
\hline - Room service was prompt. & 2.68 & 1.40 \\
\hline $\begin{array}{l}\text { - Check-in and check-out procedures were fast and } \\
\text { efficient. }\end{array}$ & 4.40 & 0.68 \\
\hline \multirow{2}{*}{\multicolumn{3}{|c|}{ Table 6 Continued }} \\
\hline Variables & & St.D \\
\hline \multicolumn{3}{|l|}{ (5)Competence Dimension } \\
\hline $\begin{array}{l}\text { - Employees were knowledgeable about available } \\
\text { services and facilities in surrounding area. }\end{array}$ & 4.27 & 0.69 \\
\hline $\begin{array}{l}\text { Employees were knowledgeable about the } \\
\text { ecological facilities in the property. }\end{array}$ & 4.25 & 0.68 \\
\hline - Employees knew about local places of interest. & 4.20 & 0.73 \\
\hline \multicolumn{3}{|l|}{ (6)Courtesy Dimension } \\
\hline - Employees were consistently courte & 4.20 & 0.90 \\
\hline - Employees treated you with respect. & 4.22 & 0.76 \\
\hline \multicolumn{3}{|l|}{ (7)Security Dimension } \\
\hline - The eco-lodge provided a safe environment. & 4.18 & 0.75 \\
\hline - Employees at the front desk protected your privacy. & 4.18 & 0.75 \\
\hline - Safe storage of belonging & 3.92 & 1.12 \\
\hline \multicolumn{3}{|l|}{ (8)Access Dimension } \\
\hline - The restaurant was open at suitable hours. & 4.10 & \multirow{2}{*}{0.85} \\
\hline - Room service was available at convenient hours. & 2.63 & \\
\hline - Your room loc & \multirow{2}{*}{$\frac{4.30}{4.10}$} & \multirow{2}{*}{0.81} \\
\hline - Parking arrangements were provided. & & \\
\hline $\begin{array}{c}\text { - The facilities in the eco-lodge were conveniently } \\
\text { located. }\end{array}$ & 4.15 & $\begin{array}{ll}0.99 \\
0.72\end{array}$ \\
\hline \multirow{2}{*}{$\begin{array}{l}\text { - A manager was available if you had a problem. } \\
\text { (9)Communication Dimension }\end{array}$} & \multirow[t]{2}{*}{4.14} & \multirow{2}{*}{0.79} \\
\hline & & \\
\hline \multirow{2}{*}{\multicolumn{3}{|c|}{$\begin{array}{l}\text { account were clearly ex } \\
\text { Table } 6 \text { Continued }\end{array}$}} \\
\hline & & \\
\hline $\begin{array}{c}\text { Variables } \\
\end{array}$ & \multirow{2}{*}{$\frac{\text { Mean }}{4.20}$} & t.D \\
\hline - You received undivided attention at the front desk. & & 0.72 \\
\hline $\begin{array}{c}\text { - Employees at this eco-lodge were able to handle } \\
\text { your complaints. }\end{array}$ & 4.27 & 0.70 \\
\hline \multicolumn{3}{|l|}{ (10)Understanding Dimension } \\
\hline $\begin{array}{l}\text { - Front office clerks tried to find out your particular } \\
\text { needs. }\end{array}$ & 4.19 & 0.74 \\
\hline - Employees anticipated your needs. & 4.17 & 0.67 \\
\hline loyees & & \\
\hline
\end{tabular}

With regard to tangibility dimension, it could be concluded that the majority of respondents were strongly agreed that the investigated ecolodges' interior and exterior were well maintained and their Furnishings were appealing.

On the other hand, they disagreed that room service, served food at a satisfactory temperatures or offered a good variety of food items.

Their perceptions towards the other attributes ranged between neutral (2 items) and agree (10 items). 
Regarding with the attributes of reliability dimension; it could be noticed that, the majority of the investigated respondents strongly agreed that the eco-lodges' employees had the ability to answer their questions. They did what they had promised; their rooms were ready with accurate charges.

On the other hand; they disagreed that there was a consistent room service at the investigated eco-lodges.

Meanwhile, they were agreed on receiving the requested rooms with enough guest supplies and their orders were correctly filled in the ecolodges' restaurants.

Concerning the credibility dimension (Table 6), it could be concluded that the respondents strongly agreed with they paid for and that the eco-lodge had a good reputation. Also they agreed with the item which concerned with seeing the managers frequently in eco-lodge.

There was a strong agreement that informative literature about the eco-lodge provided and procedures of check-in and check-out were fast and efficient. The customers agreed also with three attributes (items no.29, 31 and 32), but they were neutral that room service was prompt.

Regarding to Responsiveness, Competence, Courtesy, Security, Access, Communication and Understanding dimensions, nearly the same trend was observed, there was a general agreement with the most of those dimensions' attributes. This could be summarized as follow:

- The restaurants service were prompt

- Employees were willing to answer customer's questions,

- Employees responded quickly to handle customer's problems, employees knew about local places of interest,

- Employees were consistently courteous,

- A safe environment was provided in the eco-lodge,

- Employees at the front desk protected customer's privacy,

- Safe storage of customer's belongings was available,

- The restaurant was open at suitable hours,

- Parking arrangements were provided,

- The facilities in the eco-lodge were conveniently located,

- Managers were available if customer had a problem,

- Charges on customer's account were clearly explained,

- Customers received undivided attention at the front desk,

- Front office clerks tried to find out customers' particular needs,

- Employees anticipated their needs. 
Their perceptions were neutral towards the following attributes:

- Room service was prompt.

- Room service was available at convenient hours.

Chapter Four

Results

\section{and Discussion}

Table7: Ranking of the ten dimensions' means of the customers' questionnaire forms from higher to lower

\begin{tabular}{|c|r|c|}
\hline No. & Dimension & Mean \\
\hline 1 & Competence & 4.24 \\
\hline 2 & Understanding & 4.22 \\
\hline 3 & Credibility & 4.21 \\
\hline 4 & Courtesy & 4.21 \\
\hline 5 & Communication & 4.21 \\
\hline 6 & Security & 4.09 \\
\hline 7 & Reliability & 3.98 \\
\hline 8 & Responsiveness & 3.94 \\
\hline 9 & Access & 3.90 \\
\hline 10 & Tangibility & 3.74 \\
\hline
\end{tabular}

From the data in table (7), the following conclusion could be inferred:

- The majority of the investigated respondents strongly agreed with the attributes of dimensions: Communication, Courtesy, Credibility, Understanding and Competence with an average mean that ranged from 4.21 to 4.24 meanwhile they agreed with the attributes of dimensions: Tangibility, Access, Responsiveness, Reliability, and Security with an average mean that ranged from 3.74 to 4.09 .

- $\quad$ These results agreed with that concluded by Sayed (2005) and Mohammed (2005).

\section{Q 6: Respondents' Overall Satisfactions}

This question aims to identify what extent the investigated respondents were satisfied. 
Table8: Respondents' Overall Satisfactions

\begin{tabular}{|c|c|c|}
\hline Attribute & $\begin{array}{c}\text { Frequency } \\
\text { No. }\end{array}$ & $\begin{array}{c}\text { Percentage } \\
\mathbf{\%}\end{array}$ \\
\hline Completely satisfied & 241 & 67.7 \\
\hline Somewhat satisfied & 102 & 28.7 \\
\hline (Neutral)Neither satisfied nor dissatisfied & 12 & 3.6 \\
\hline Somewhat dissatisfied & 0 & 0 \\
\hline Completely dissatisfied & 0 & 0 \\
\hline Total & $\mathbf{3 5 5}$ & $\mathbf{1 0 0}$ \\
\hline
\end{tabular}

From the results indicated in the table (8) it could be noticed that more than two third $(67.7 \%)$ of the investigated respondents were completely satisfied. The respondents who were somewhat satisfied represent $(28.7 \%)$. Meanwhile (3.6\%) of them were neutral. These results reflected the positive perceptions of the investigated respondents towards the quality of hospitality services provided in the investigated eco-lodges.

\section{Conclusion}

As a final conclusion, there is a positive perceptions and general satisfaction towards the quality of the hospitality services provided in the investigated eco-lodges. Also there were some weakness points such as: guest supplies were very little in some investigated eco-lodges, employees' uniform was not constant, Room rates were high, the outdoor surroundings were sometimes not clean and no safe storages were founded. So, management should focus on improvement and pay more attention to enhance it to fully meet the customers' perceptions and expectations.

\section{Recommendations}

Based on the results obtained from both theoretical and field studies. The following recommendations could be inferred and proposed to be applied:

- Improving the level of accommodation services through:

- Increasing the number of eco-lodges' rooms to extent allowed by the standards for the eco-lodge in order to increase the capacity to accommodate larger numbers of new customers.

- Increasing guest supplies in rooms such as (soap, towels ...etc).

- Enhancing the level of housekeeping service.

- Adopting periodical contracts for pests control with specialized establishments in order to keep the eco-lodges' rooms clean and free of insects and rodents.

- Enhancing the level of food and beverages services through: 
- Offering a variety in menu items and applying standard recipes of menus' items.

- Putting the special categories and groups into consideration (such as diabetics, athletes, children...etc).

- Providing room service to eco-lodges that do not provide and improving it in the eco-lodges that already offer it.

- Improving the entertainment and recreational services within the ecolodges by:

- Establishing a bazaar to sell local products and handicrafts.

- Adding some recreational facilities within the eco-lodges such as: (library, stargazing, horse riding ... etc.)

- Using of the natural hot springs surround the eco-lodges in customers' recreation and recovering.

- $\quad$ Raising the level of employees' performance to be more effective and efficient through:

- Establishing a set of training courses and programs that helps ecolodges' employees to improve their personal, practical and behavioral skills and their languages to have a high level of customer communication.

- Paying attention to the employees' appearance and provide them with uniforms.

- Marketing activities for eco-lodges and its' hospitality services should be increased to be known for more customers and categories.

- Continuous cooperation between the management of the eco-lodges and the governmental establishments in order to preserve the cleanliness of the outdoor surroundings of the eco-lodges and the preservation of its' natural characteristics.

- Continuous evaluation of the quality of accommodation services, recreation services, food and beverage services provided by the eco-lodge to determine the customer overall satisfaction about hospitality services. 


\section{References}

\section{English References}

\section{Books}

- Gianesi, I.G.N, and Corrêa, H.L. (2004)."Strategic Management Services: Operations to Customer Satisfaction". São Paulo Press: Atlas.pp.114-116.

- Hoffman, K.D., and Bateson, J.E.G. (2001)."Essentials of Service Marketing". The Dryden Press, Hinsdale, IL, pp12-13.

- Lovelocke, C. H. (2001)."Service Marketing: People, technology, strategy". 4th edition, Engelwood Cliffs, NJ: Prentice Hall, pp.299-302.

- Mehta, H. (2007)."Towards an Internationally Recognized Eco-lodge Certification. In Black, R. and Crabtree, A. (Eds.)". Ecotourism series, number 5: Quality Assurance and Certification in Ecotourism. CABI Publishing, London, pp.415- 434.

\section{B) Journal articles}

- Bowen, J. and Chen, S. (2001). "The Relationship between Customer Loyalty and Customer Satisfaction". International Journal of Contemporary Hospitality Management, 13(5), pp.213-217.

- Ceballos-Lascurain, H. (2008)."The Future of Ecotourism". Mexico Journal, pp.13-14.

- Chiou, Jyh-Shen and Shen Chi-Chung, (2006). "The Effects of Satisfaction, Opportunism, And Asset Specificity on Consumers' Loyalty Intention toward Internet Portal Sites", International Journal Service Industry Management, 17, 1, pp.7-22.

- Cho, S., Wood, R.H., Jang, S. and Erdem, M. (2006)."Measuring the impact of human research management practices on hospitality firm's performances. Hospitality Management Journal, (25), pp.262 - 277.

- Didin, S. and Köroğlu, Ç. (2008), "The competitiveness of accommodation firms with regard to sales-costs and their future expectations. Zonguldak Karaelmas University Journal of Social Sciences, (7), pp.111 - 120.

- Eshghi, A., Roy, S., and Ganguli, S. (2008). "Service quality and customer satisfaction: An Empirical Investigation in Indian Mobile Telecommunications Services". Marketing Management Journal, 18(2), pp.119-144.

- Holjevac, I.A. (2003). "A vision of tourism and hotel industry in the 21st century. Hospitality Management Journal, (22), pp.129 - 134.

- Jones, M.A., Beatty, S.E. and Mothersbaugh, D.V. (2002)."Why Customers Stay". Measuring the Underlying Dimensions of Services Switching Costs 
and Managing Their Differential Strategic Outcomes. Journal of Business. Res., 55(3), pp. 44-50.

-Kosar, L.and Rašeta, S. (2005). "Challenges of Quality", The College of Hotel Management Series, Belgrade, pp.145-147.

- Minazzi, R. (2008)."Customer Satisfaction Survey in the Hospitality Industry: Comparison of International Hotel Chains Questionnaires". Milano: Universita IULM.pp25-29.

- Nadiri, H and Hussain, K. (2005), "Diagnosing the Zone of Tolerance for Services, Managing Service Quality" .International Journal of Contemporary Hospitality Management, 15(3), 259-277.

- Sandoff, M, (2005), "Customization and Standardization in Hotels- a Paradox or Not?".International Journal of Contemporary Hospitality Management, 17(6), pp. 529-535.

- Vanacore, A. and P. Erto, (2002). "A Probabilistic Approach to Measure Hotel Service Quality". International Journal of Hospitality Management, 13(2), pp.165-174.

- Wood, M.E. (2002)."Ecotourism Principles, Practices \& Policies for Sustainability". United Nations Publication, France, 50(7), pp.230-237.

- Zeithaml, V. A. (2000). "Service Quality, Profitability and the Economic worth of Customers: What We Know and What We Need to Learn", Journal of the Academy of Marketing Science 28(1), pp.67-85.

\section{C) Reports}

- Bohdanowicz, P., Simanic, B. and Martinac, I. (2005)." Sustainable hotels - environmental reporting according to green globe 21, green globes Canada / Gem UK, IHEI bench mark hotel and Hilton environmental reporting. The 2005 World Sustainable Building Conference. 27-29 September, Tokyo, Japan, pp.164 - 166.

-Egyptian Hotel Association. (2013). "Egyptian Hotel Guide", $33^{\text {rd }}$ edition, Cairo, Egypt.

- International Finance Corporation. (2004), "Ecolodges: Exploring opportunities for sustainable business". International Finance Corporation Publication, Washington.

\section{D) Thesis and Ph.Ds}

- Dizdareviç, S. (2010), "The analyze of ecotourism supply potential in Northern part of Montenegro". Unpublished Master's Thesis, Dokuz Eylül University Social Sciences Institute, İzmir, Turkey. 
مجلة كلية السياحة والفنادق - عدد r - ديسمبر r.lV

- Joshi, R.L., (2011)."Eco-tourism Planning and Management on Eco-tourism Destinations of Bajhang District", Nepal. M. Sc. Forestry (2010-2012), p.11.Online (Available):http://www.forestrynepal.org/images/ publications/ Ecotourism \%20 destination \%20bajhang.pdf.

- Mohammed, B. (2005)."Development of Hospitality Services in Baharia Oasis. Thesis Submitted to Obtain a Master's Degree in Hotel Management. Helwan University, Egypt. Arabic Summary, pp.4-6

- Sayed, A (2005)."Evaluating Hospitality Services Offered in Siwa Oasis. Thesis Submitted to Obtain a Master's Degree in Hotel Management. Helwan University, Egypt, pp.140-161

\section{Arabic References}

$$
\begin{aligned}
& \text { فتحى ماله" .(2015) دليل واحة سيوة ."مكتبة الواحة , واحة سيوة . الطبعة الأولى صفحات } \\
& \text { 27, 61-62. }
\end{aligned}
$$

